\title{
Use of nitrogen from fertilizer and cover crops by upland rice in an Oxisol under no-tillage in the Cerrado
}

\author{
Edson Cabral da Silva( ${ }^{(1)}$, Takashi Muraoka ${ }^{(1)}$, Vinícius Ide Franzini(2), Karuppan Sakadevan ${ }^{(3)}$, Salatiér Buzetti(4), \\ Orivaldo Arf ${ }^{(4)}$, José Alberto Bendassolli( ${ }^{(1)}$ and Frederico Antônio Loureiro Soares ${ }^{(5)}$
}

\begin{abstract}
(1)Universidade de São Paulo, Centro de Energia Nuclear na Agricultura, Avenida Centenário, № 303, São Dimas, CEP $13416-000$ Piracicaba, SP, Brazil. E-mail: edsoncabralsilva@gmail.com, muraoka@cena.usp.br, jab@cena.usp.br (2)Embrapa Amazônia Oriental, Travessa Dr. Enéas Pinheiro, s/no, Marco, Caixa Postal 48, CEP 66095-903 Belém, PA, Brazil. E-mail: vinicius.franzini@embrapa.br (3)Joint FAO/IAEA Division of Nuclear Techniques in Food and Agriculture, Soil and Water Management \& Crop Nutrition Subprogram, Vienna International Centre, PO Box 100, A-1400 Vienna, Austria. E-mail: K.Sakadevan@iaea.org (4)Universidade Estadual Paulista Júlio de Mesquita Filho, Faculdade de Engenharia, Avenida Brasil, no 56, Centro, CEP 15385-000 Ilha Solteira, SP, Brazil. E-mail: sbuzetti@agr.feis.unesp.br, arf@agr.feis.unesp.br ${ }^{(5)}$ Instituto Federal Goiano, Campus Rio Verde, Rodovia Sul Goiana, Km 01, Zona Rural, CEP 75901-970 Rio Verde, GO, Brazil. E-mail: fredalsoares@hotmail.com
\end{abstract}

Abstract - The objective of this work was to evaluate the effects of cover crops on the yield of upland rice (Oryza sativa) grown under no-tillage system, in the presence and absence of $\mathrm{N}$ fertilizer, as well as to quantify, in the field, the use efficiency of $\mathrm{N}$ from urea and cover crops by upland rice, through the ${ }^{15} \mathrm{~N}$ isotope dilution technique. The field experiment was carried out in the municipality of Selvíria, in the state of Mato Grosso do Sul, Brazil, in an Oxisol (Rhodic Hapludox) in the Cerrado (Brazilian savanna) region. The experimental design was a randomized complete block with 15 treatments and four replicates, in a $5 \times 3$ factorial arrangement. The treatments were four cover crops (Crotalaria juncea, Cajanus cajan, Mucuna pruriens, and Pennisetum glaucum) + spontaneous vegetation (fallow in off-season), combined with three forms of $\mathrm{N}$ fertilization: control treatment, without $\mathrm{N}$ fertilizer application; $20 \mathrm{~kg} \mathrm{ha}^{-1} \mathrm{~N}$ at sowing; and $20 \mathrm{~kg} \mathrm{ha}^{-1} \mathrm{~N}$ at sowing plus $60 \mathrm{~kg} \mathrm{ha}^{-1}$ $\mathrm{N}$ as topdressing. Rice is not affected by $\mathrm{N}$ fertilizer application as topdressing, when legume cover crops are used. The use of legume cover crops provides higher grain yield and use of fertilizer-N by rice than that of millet or fallow. Legume cover crops promote an effect equivalent to that of the application of $60 \mathrm{~kg} \mathrm{ha}^{-1} \mathrm{~N}$ as urea on rice yield.

Index terms: Oryza sativa, crop residues, isotope technique, mineralization, ${ }^{15} \mathrm{~N}$, nutrient cycling.

\section{Aproveitamento de nitrogênio de fertilizante e plantas de cobertura pelo arroz de terras altas em Latossolo Vermelho sob plantio direto no Cerrado}

\begin{abstract}
Resumo - O objetivo deste trabalho foi avaliar os efeitos do uso de plantas de cobertura sobre a produtividade do arroz (Oryza sativa) de terras altas cultivado em sistema plantio direto, na presença e na ausência de adubação nitrogenada, bem como quantificar, em campo, o aproveitamento de $\mathrm{N}$ da ureia e de plantas de cobertura pelo arroz, com emprego da técnica de diluição isotópica de ${ }^{15} \mathrm{~N}$. O experimento de campo foi realizado em Selvíria, MS, em um Latossolo Vermelho distroférrico, na região do Cerrado. O delineamento experimental foi o de blocos ao acaso com 15 tratamentos e quatro repetições, em arranjo fatorial $5 \times 3$. Os tratamentos foram quatro espécies de plantas de cobertura (Crotalaria juncea, Cajanus cajan, Mucuna pruriens e Pennisetum glaucum) + vegetação espontânea (pousio), combinados com três formas de adubação nitrogenada: controle, sem aplicação de $\mathrm{N} ; 20 \mathrm{~kg} \mathrm{ha}^{-1} \mathrm{de} \mathrm{N}$ em semeadura; e $20 \mathrm{~kg} \mathrm{ha}^{-1}$ de $\mathrm{N}$ em semeadura mais $60 \mathrm{~kg} \mathrm{ha}^{-1} \mathrm{de} \mathrm{N}$ em cobertura. $\mathrm{O}$ arroz não responde à aplicação de $\mathrm{N}$ em cobertura, quando leguminosas são usadas como plantas de cobertura. $\mathrm{O}$ uso de leguminosas como planta de cobertura resulta em maior produtividade de grãos e aproveitamento do $\mathrm{N}$ do fertilizante pelo arroz do que o uso de milheto ou pousio. As leguminosas proporcionam efeito equivalente à aplicação de $60 \mathrm{~kg} \mathrm{ha}^{-1}$ de $\mathrm{N}$ na forma de ureia sobre a produtividade de grãos de arroz.
\end{abstract}

Termos para indexação: Oryza sativa, resíduos culturais, técnica isotópica, mineralização, ${ }^{15} \mathrm{~N}$, ciclagem de nutrientes.

\section{Introduction}

Rice (Oryza sativa L.) is the most important cereal for global food security, and Brazil is the world largest producer of upland rice, also known as aerobic rice, which is grown mainly in Asia, Africa, and Latin America (Fageria et al., 2010). In Brazil, the average grain yield of upland rice is lower than that of lowland

Pesq. agropec. bras., Brasília, v.51, n.6, p.728-737, jun. 2016

DOI: 10.1590/S0100-204X2016000600004 
rice (Santos \& Rabelo, 2008), partly due to low soil fertility and nutrient deficiency, which is one of the most important yield-limiting factors in upland rice production systems (Fageria et al., 2008; Nascente et al., 2013a).

Most upland rice crops are located in the Cerrado region, whose soils have low fertility (Fageria et al., 2011). Among the rice crop management practices adopted, $\mathrm{N}$ application through fertilizer and cover crops provides better yield (Scivittaro et al., 2005). Therefore, it is important to know the capacity of cover crops to supply $\mathrm{N}$ for crop production (Nascente et al., 2013b; Pacheco et al., 2013).

Rice has been used as a pioneer crop in areas of agricultural frontiers, and, currently, with the reduced opening of new agricultural areas, it has also been used in cropping systems with crop rotation, especially in areas under no-tillage (Moro et al., 2013; Nascente et al., 2013a), in which straw as ground cover is essential for the sustainability of the system. Rice cultivation in no-tillage cover crops is of great interest because of the nutrients released by the crop residue, such as $\mathrm{N}$ available as ammonium (Torres et al., 2008; Teixeira et al., 2009; Nascente et al., 2013a, 2013b), which is essential for the initial development of rice (Holzschuh et al., 2009; Nascente et al., 2013a; Pacheco et al., 2013).

The availability of $\mathrm{N}$ by crop residues is related to the $\mathrm{C} / \mathrm{N}$ ratio of the residue. Legume cover crops used as plant cover provide greater contribution to soil N (Silva et al., 2009; Carvalho et al., 2011; Teodoro et al., 2011) and can increase upland rice productivity in succession to cover crops under no-tillage (Cazetta et al., 2008). Grasses increase the permanence of residues on soil surface, which can be attributed to a higher $\mathrm{C} / \mathrm{N}$ ratio, and, consequently, a lower decomposition rate (Boer et al., 2008; Torres et al., 2008; Teixeira et al., 2009; Pacheco et al., 2013).

The intensive and inappropriate use of soil for agricultural production reduces soil fertility and aggravates the degradation of soil organic matter (SOM). The application of cover crops that supply plant residues helps to maintain and even increase SOM and improves soil fertility (Tejada et al., 2008; Carvalho et al., 2011). The use of legume cover crops can also add $\mathrm{N}$ through biological $\mathrm{N}$ fixation. Additional benefits of cover crops are providing greater protection and aeration to soil, which promotes root growth and development, with positive impact, such as increased water and nutrient retention, infiltration, and water and nutrient availability for the crop (Cherr et al., 2006).

The effectiveness of cover crops as a source of nutrients varies among species and cultivars, and also with its integrated use with mineral fertilizer. Both cover crops and mineral fertilizers are important to increase the efficiency of fertilizer use (Muraoka et al., 2002; Scivittaro et al., 2008; Carvalho et al., 2011). It should be highlighted that $\mathrm{N}$ is one of the most yield-limiting nutrients in crop production, particularly for cereals, in all regions of the world (Fageria et al., 2011). The main reason for $\mathrm{N}$ deficiency in annual crops is its low recovery efficiency. In cereals, $\mathrm{N}$ recovery efficiency at a global level is reported to be less than $40 \%$ (Raun et al., 2002). This low recovery efficiency is associated with losses by leaching, denitrification, volatilization, and soil erosion (Raun et al., 2002; Fageria et al., 2008).

The use of the isotope technique through labeling cover crop nutrients (e.g. ${ }^{15} \mathrm{~N}$ ) allows to measure $\mathrm{N}$ recovery, with precise information on the nutrient-supplying capacity of cover crops and on the dynamics of $\mathrm{N}$ in the soil-plant system (Muraoka et al., 2002; Raun et al., 2002).

The objective of this work was to evaluate the effects of cover crops on the yield of upland rice grown under no-tillage system, in the presence and absence of $\mathrm{N}$ fertilizer, as well as to quantify, in the field, the use efficiency of $\mathrm{N}$ from urea and cover crops by upland rice, through the ${ }^{15} \mathrm{~N}$ isotope dilution technique.

\section{Materials and Methods}

The field experiment was carried out in the experimental farm of the engineering college of Universidade de São Paulo, located in the municipality of Selvíria, in the state of Mato Grosso do Sul, Brazil $\left(51^{\circ} 22^{\prime} \mathrm{W}, 20^{\circ} 22^{\prime} \mathrm{S}\right.$, at $335 \mathrm{~m}$ of altitude). The soil is classified as a loamy, cerrado phase Latossolo Vermelho distroférrico (Santos et al., 2013), i.e, a Typic Rhodic Hapludox (United States Department of Agriculture, 2010). The experimental area has a history of 19 years under conventional tillage of which the last 11 years were under no-tillage. The local climate is Aw according to Köppen's classification (Alvares et al., 2013).

The initial chemical characterization of the soil, analyzed according to the methodology described by

Pesq. agropec. bras., Brasília, v.51, n.6, p.728-737, jun. 2016 DOI: 10.1590/S0100-204X2016000600004 
Raij et al. (2001), in the $0-0.10$ and $0.10-0.20-\mathrm{m}$ soil layers were, respectively: 4.9 and $4.7 \mathrm{pH}\left(\mathrm{CaCl}_{2}\right)$; 1.0 and $0.8 \mathrm{~g} \mathrm{~kg}^{-1}$ total $\mathrm{N} ; 26$ and $22 \mathrm{~g} \mathrm{dm}^{-3}$ organic matter; 30 and $25 \mathrm{mg} \mathrm{dm}^{-3} \mathrm{P}$ (resin extractable); 32 and $20 \mathrm{mmol}_{\mathrm{c}} \mathrm{dm}^{-3} \mathrm{Ca} ; 18$ and $12 \mathrm{mmol}_{\mathrm{c}} \mathrm{dm}^{-3} \mathrm{Mg} ; 2.0$ and $2.6 \mathrm{mmol}_{\mathrm{c}} \mathrm{dm}^{-3} \mathrm{~K} ; 31$ and $38 \mathrm{mmol}_{\mathrm{c}} \mathrm{dm}^{-3} \mathrm{H}+\mathrm{Al}$; 4.0 and $3.5 \mathrm{mg} \mathrm{dm}^{-3} \mathrm{~S}$; cation exchange capacity of 83 and $72.6 \mathrm{mmol}_{\mathrm{c}} \mathrm{dm}^{-3}$; and base saturation of 62.7 and $47.7 \%$.

The experimental design was a randomized complete block with 15 treatments and four replicates, in a $5 \times 3$ factorial arrangement. The treatments were four cover crop species: sunn hemp (Crotalaria juncea L.), pigeon pea [Cajanus cajan (L.) Millsp.], green velvet bean [Mucuna pruriens (L.) DC.], and pearl millet [Pennisetum glaucum (L.) R.Br] + spontaneous vegetation (fallow soil in off-season), with or without mineral $\mathrm{N}$ fertilization as urea on upland rice grown in succession to the cover crops. The treatments with $\mathrm{N}$ fertilization were: control treatment, without $\mathrm{N}$ fertilizer application; $20 \mathrm{~kg} \mathrm{ha}^{-1} \mathrm{~N}$ at sowing; and $20 \mathrm{~kg} \mathrm{ha}^{-1} \mathrm{~N}$ at sowing plus $60 \mathrm{~kg} \mathrm{ha}^{-1} \mathrm{~N}$ as topdressing.

The field experiment consisted of two phases. In the first one (winter/spring season), cover crops were sown $0.40 \mathrm{~m}$ between rows for sunn hemp, pigeon pea, and velvet bean, and $0.25 \mathrm{~m}$ for millet; and an area was left with spontaneous vegetation during fallow off-season. In the second phase (spring/summer season), upland rice was grown under no-tillage on soil covered by cover crop residues, with or without the application of mineral $\mathrm{N}$ fertilizer.

The used plants of ${ }^{15} \mathrm{~N}$-labeled sunn hemp, pigeon pea, velvet bean, and pearl millet were grown simultaneously in an area adjacent to the main experiment, in $2 \times 5-\mathrm{m}$ microplots, with the application of $40 \mathrm{~kg} \mathrm{ha}^{-1} \mathrm{~N}$ as urea- ${ }^{15} \mathrm{~N}\left(10.37 \%\right.$ atoms ${ }^{15} \mathrm{~N}$ excess $)$ in three equal splits at 20,34, and 48 days after emergence - first application to the soil; second application half to the soil and half to the leaves, and third application only to the leaves. The ${ }^{15} \mathrm{~N}$-labeled plants were harvested at the same time as the unlabeled ones. Both ${ }^{15} \mathrm{~N}$-labeled and unlabeled plants were cut into small pieces, and samples were taken for chemical and isotopic ${ }^{15} \mathrm{~N}$ analysis. Regarding spontaneous vegetation, no plants were unlabeled with ${ }^{15} \mathrm{~N}$.

In the cover crop microplots, unlabeled plant material of sunn hemp, pigeon pea, velvet bean, and pearl millet was substituted by the equivalent amount of ${ }^{15} \mathrm{~N}$-labeled plants, i.e., $1.39,1.16,1.74$, and $2.11 \%$ atoms ${ }^{15} \mathrm{~N}$, respectively.

Cover crops and spontaneous vegetation were cut mechanically with straw crusher and chemically with herbicide, up to 70 days after sowing (DAS); the crop residues were left on soil surface and used as mulch in the field.

In succession to cover crops (spring/ summer season), the upland rice crop, cultivar IAC 202, was sown mechanically (second phase), at a $0.35-\mathrm{m}$ spacing between rows and a density of approximately 200 seeds per square meter, in 60 main plots, each $8 \times 12 \mathrm{~m}$. In each main plot, one 1.0x2.1-m microplot (equivalent to six rice rows) was set for ${ }^{15} \mathrm{~N}$-labelled fertilizer (2.5 atom \% excess ${ }^{15} \mathrm{~N}$-enriched urea) and/ or cover crop residues, which were: sunn hemp $=1.39$ atoms $\%{ }^{15} \mathrm{~N}$; pigeon pea $=1.16$ atoms $\%{ }^{15} \mathrm{~N}$; velvet bean $=1.74$ atoms $\%{ }^{15} \mathrm{~N}$; and pearl millet $=2.11$ atoms $\%{ }^{15} \mathrm{~N}$. The urea- ${ }^{15} \mathrm{~N}$ and ${ }^{15} \mathrm{~N}$-labelled cover residues were added on different microplots, to distinguish $\mathrm{N}$ derived from the respective sources of this nutrient.

Basal phosphorus and potassium fertilizer were applied as triple superphosphate $\left(40 \mathrm{~kg} \mathrm{ha}^{-1} \mathrm{P}_{2} \mathrm{O}_{5}\right)$ and potassium chloride (40 $\mathrm{kg} \mathrm{ha}^{-1} \mathrm{~K}_{2} \mathrm{O}$ ), respectively. A total of $20 \mathrm{~kg} \mathrm{ha}^{-1} \mathrm{~N}$ fertilizer, as urea, was applied manually after sowing, whereas $60 \mathrm{~kg} \mathrm{ha}^{-1} \mathrm{~N}$ as topdressing was applied between rows at the beginning of the panicle differentiation stage.

During the prolonged dry season periods, supplemental sprinkler irrigation was applied for cover crops and upland rice. Rice plant tops were harvested at 113 DAS, and the following were measured: grain yield, straw, $\mathrm{N}$ content, $\mathrm{N}$ accumulation, $\mathrm{N}$ in the plant derived from urea and cover crops, $\mathrm{N}$-fertilizer use, and $\mathrm{N}$ in the plant derived from the soil. Rice yield was determined outside the microplots by weighing the grains of six 5-m long rows.

The $\mathrm{C}$ and $\mathrm{N}$ contents of cover crop residues were determined by the dry combustion method $\left(1,400^{\circ} \mathrm{C}\right)$, using the Leco CN-2000 analyzer (Leco Corporation, St. Joseph, MI, USA) (Nelson \& Sommers, 1982). The determinations of total $\mathrm{N}$ and atoms $\%{ }^{15} \mathrm{~N}$ abundance in vegetable material, that is, in cover crops, grains, and rice straw, were performed using isotope ratio mass spectrometry (IRMS) with an automatic analyzer ANCA-SL 20-20 (Europe Scientific Ltd., Crewe, UK), according to the methodology described by Barrie \& Prosser (1996). 
The following were calculated according to International Atomic Energy Agency (2001), Asagi \& Ueno (2009), and Zhu et al. (2014): total accumulated $\mathrm{N}$; percentage (Ndfcc) and quantity in $\mathrm{kg} \mathrm{ha}{ }^{-1}$ (QNdfcc) of $\mathrm{N}$ in rice plant derived from cover crops and from urea (Ndff in percentage and Ndff in $\mathrm{kg} \mathrm{ha}^{-1}$, respectively); and use efficiency of $\mathrm{N}$ from cover crop and urea by rice plants.

The calculations of total accumulated $\mathrm{N}\left(\mathrm{kg} \mathrm{ha}^{-1}\right)$, Ndfcc, and QNdfcc in rice plant derived from Ndff and QNdff, as well as use efficiency of $\mathrm{N}$ from cover crop and urea by rice plants were performed according to Asagi \& Ueno (2009) and Zhu et al. (2014).

The contribution of $\mathrm{N}$ from cover crops equivalent to $\mathrm{N}$ fertilizer (urea) was obtained by the first derivative of the quadratic polynomial function: $\mathrm{y}=\mathrm{c}+\mathrm{bN}-\mathrm{AN}^{2}$, equaling it to the productivity, without $\mathrm{N}$ application, of the cover crop that provided the highest rice grain yield.

Data were analyzed statistically by the $\mathrm{F}$ test, and means were compared by Tukey's test, at 5\% probability. Statistical analyses were carried out using the SAS package, version 8.2 (SAS Institute, Cary, NC, USA).

\section{Results and Discussion}

Shoot dry matter (SDM) productivity of the cover crops followed the decreasing order: sunn hemp $\left(11.3 \mathrm{Mg} \mathrm{ha}^{-1}\right)>\operatorname{millet}\left(7.4 \mathrm{Mg} \mathrm{ha}^{-1}\right)>$ pigeon pea $(6.1$ $\left.\mathrm{Mgha}^{-1}\right)>$ green velvet bean $\left(4.0 \mathrm{Mgha}^{-1}\right)>$ spontaneous vegetation (3.1 $\mathrm{Mg} \mathrm{ha}^{-1}$ ) (Table 1). Bordin et al. (2003) obtained lower SDM for sunn hemp (6.9 $\left.\mathrm{Mg} \mathrm{ha}^{-1}\right)$ compared to millet $\left(9.6 \mathrm{Mg} \mathrm{ha}^{-1}\right)$. In another study carried out in the municipality of Selvíria, in the state of Mato Grosso do Sul, also under no-tillage, Cazetta et al. (2008) obtained, in two consecutive crops, lower SDM for sunn hemp, pigeon pea, and spontaneous vegetation (fallow), when plants were cut at 60 DAS, besides higher values for velvet bean and similar ones for millet. In general, biomass production and nutrient uptake is an intrinsic characteristic of each cover crop species (Carvalho et al., 2011; Pacheco et al., 2013). However, biomass production of cover crops is also affected by environmental conditions, soil fertility, and crop management practices (Fageria et al., 2005).

Sunn hemp $\left(\mathrm{N}=17.5 \mathrm{~g} \mathrm{~kg}^{-1}\right.$ and $\left.\mathrm{C} / \mathrm{N}=24.3\right)$, green velvet bean $\left(\mathrm{N}=27.2 \mathrm{~g} \mathrm{~kg}^{-1}\right.$ and $\left.\mathrm{C} / \mathrm{N}=15.2\right)$, and pigeon pea (23.3 g kg${ }^{-1}$ and $\left.\mathrm{C} / \mathrm{N}=18.4\right)$ had a higher $\mathrm{N}$ concentration in dry matter and a lower $\mathrm{C} / \mathrm{N}$ ratio than millet (11.3 $\mathrm{g} \mathrm{kg}^{-1}$ and $\left.\mathrm{C} / \mathrm{N}=35.8\right)$ and spontaneous vegetation (11.8 $\mathrm{g} \mathrm{kg}^{-1}$ and $\left.\mathrm{C} / \mathrm{N}=35.5\right)$ (Table 1). This was expected since legume crop residues contain high levels of $\mathrm{N}$ when compared with non-legume crops due to their ability to fix atmospheric $\mathrm{N}$ through biological nitrogen fixation (BNF) and to absorb it in the plant tissues (Silva et al., 2009; Carvalho et al., 2011; Teodoro et al., 2011).

The ${ }^{15} \mathrm{~N}$ enrichment of cover crops showed that millet $(2.112 \%)$ had higher ${ }^{15} \mathrm{~N}$ enrichment than the legumes pigeon pea, sunn hemp, and velvet bean, with $1.163,1.393$, and $1.741 \%$, respectively (Table 1 ). This is likely to occur because of the symbiotic association between legumes with bacteria of the genus Rhizobium, which promotes BNF of atmospheric N, diluting the ${ }^{15} \mathrm{~N}$ applied as fertilizer (Silva et al., 2006). Studies have shown that the $\mathrm{N}$ derived from $\mathrm{BNF}$ in legume manures is usually, on average, more than $60 \%$ of the

Table 1. Dry matter yield, $\mathrm{N}$ content, accumulated $\mathrm{N},{ }^{15} \mathrm{~N}$ concentration, $\mathrm{C}$ content, $\mathrm{C} / \mathrm{N}$ ratio, lignin, and total phenols in shoot of sunn hemp (Crotalaria juncea), pigeon pea (Cajanus cajan), green velvet bean (Mucuna pruriens), pearl millet (Pennisetum glaucum), and spontaneous vegetation, grown before rice (Oryza sativa) cultivation in the municipality of Selvíria, in the state of Mato Grosso do Sul, Brazil ${ }^{(1)}$.

\begin{tabular}{|c|c|c|c|c|c|c|c|c|}
\hline Cover crops & $\begin{array}{l}\text { Dry matter } \\
\left(\mathrm{Mg} \mathrm{ha}^{-1}\right)\end{array}$ & $\begin{array}{l}\mathrm{N} \text { content } \\
\left(\mathrm{g} \mathrm{kg}^{-1}\right)\end{array}$ & $\begin{array}{l}\text { Accumulated } \mathrm{N} \\
\left(\mathrm{kg} \mathrm{ha}^{-1}\right)\end{array}$ & $\begin{array}{c}{ }^{15} \mathrm{~N} \text { concentra- } \\
\text { tion }(\%)\end{array}$ & $\mathrm{C}\left(\mathrm{g} \mathrm{kg}^{-1}\right)$ & $\mathrm{C} / \mathrm{N}$ ratio & Lignin & Phenols $^{(2)}$ \\
\hline Sunn hemp & $11.25 \mathrm{a}$ & $17.5 \mathrm{~b}$ & $196.88 \mathrm{a}$ & 1.393 & 426 & $24.3 b c$ & $107.3 \mathrm{c}$ & $4.96 \mathrm{~b}$ \\
\hline Pigeon pea & $6.13 \mathrm{c}$ & $23.3 \mathrm{a}$ & $142.83 b$ & 1.163 & 438 & $18.4 \mathrm{c}$ & $146.4 b$ & $7.44 b$ \\
\hline Velvet bean & $4.02 \mathrm{~d}$ & $27.2 \mathrm{a}$ & $109.34 \mathrm{c}$ & 1.741 & 414 & $15.2 \mathrm{c}$ & $202.4 \mathrm{a}$ & $5.35 b$ \\
\hline Pearl millet & $7.43 b$ & $11.3 \mathrm{c}$ & $83.96 \mathrm{~d}$ & 2.112 & 405 & $35.8 \mathrm{a}$ & $80.4 \mathrm{c}$ & $7.22 b$ \\
\hline Spontaneous vegetation & $3.05 \mathrm{e}$ & $11.8 \mathrm{c}$ & $35.99 \mathrm{e}$ & - & 419 & $35.5 \mathrm{a}$ & $87.6 \mathrm{c}$ & $19.42 \mathrm{a}$ \\
\hline
\end{tabular}

${ }^{(1)}$ Values followed by equal letters in the columns do not differ significantly by Tukey's test, at $5 \%$ probability. ${ }^{(2)}$ Values expressed in equivalent grams of tannic acid per kg of dry matter. 
accumulated fraction for green manures or cover crops (Muraoka et al., 2002; Scivittaro et al., 2004).

The highest levels of lignin occurred in green velvet bean $\left(202 \mathrm{~g} \mathrm{~kg}^{-1}\right)$ followed by pigeon pea $\left(146 \mathrm{~g} \mathrm{~kg}^{-1}\right)$, whereas the lowest ones were observed in millet $\left(80 \mathrm{~g} \mathrm{~kg}^{-1}\right)$ and spontaneous vegetation (88 $\left.\mathrm{g} \mathrm{kg}^{-1}\right)$ (Table 1); however, the highest total phenol contents occurred in spontaneous vegetation. The decomposition of crop residues is associated with their chemical and organic composition, especially the contents of cellulose, hemicellulose, lignin, polyphenols and $\mathrm{N}$, as well as with their ratios, such as $\mathrm{C} / \mathrm{N}, \mathrm{C} / \mathrm{P}$, lignin/ $\mathrm{N}$, polyphenols/ $\mathrm{N}$, and polyphenols + lignin $/ \mathrm{N}$ (Cherr et al., 2006; Carvalho et al., 2011; Pacheco et al., 2013). The residues containing low concentrations of $\mathrm{N}$ and high lignin and polyphenol contents decompose and release nutrients at a slower rate (Boer et al., 2008; Silva et al., 2009). Moreover, the $\mathrm{C} / \mathrm{N}$ ratio alone does not represent well the decomposition process of organic materials since it does not consider the quality of carbon (Carvalho et al., 2011).

Therefore, the rotation with legume cover crops can result in significant inputs of $\mathrm{N}$ into the soil-plant system and subsequent crops (Muraoka et al., 2002; Carvalho et al., 2011). Studies carried out by Perin et al. (2004) have shown that sunn hemp stood out regarding phytomass yield, which was 108 and $31 \%$ greater than that of spontaneous vegetation and millet, respectively, and also that the presence of sunn hemp resulted in larger contents of $\mathrm{N}$ and $\mathrm{Ca}$, whereas millet and spontaneous vegetation showed larger $\mathrm{K}$ content. These studies also showed that BNF was $61 \%$ in the intercropping with millet and $57 \%$ in sole cropping, incorporating to the soil, via BNF, 89 and $173 \mathrm{~kg} \mathrm{ha}^{-1} \mathrm{~N}$, respectively, being an excellent strategy for increasing soil nitrogen.

With no $\mathrm{N}$ fertilizer application, rice grain yield was significantly greater in areas previously grown with legume cover crops than with millet or fallow in off-season (Table 2). There was no significant difference in rice yield among the three legume cover crops, regardless of fertilizer application (Table 2, rows). However, for each legume cover crop, fertilizer application significantly increased grain yield (Table 2, columns) compared to no fertilizer application. With $\mathrm{N}$ fertilizer application at sowing and at sowing + as topdressing, respectively, rice grain yield increased by: 23 and $36 \%$ after sunn hemp; 14 and $18 \%$ after pigeon pea; 16 and $22 \%$ after velvet bean; 28 and $66 \%$ after millet; and 41 and $75 \%$ on spontaneous vegetation (fallow in off-season).

The grain yield of rice grown after legume cover crops, with $\mathrm{N}$ fertilizer application at sowing, is not significantly different from that obtained when $\mathrm{N}$ was applied both at sowing and at sowing + as topdressing (Table 2). The highest increases in rice grain yield in response to $\mathrm{N}$ fertilizer application at sowing and at sowing + as topdressing occurred when rice was grown after millet or fallow during the growing season. This may be due to the lower $\mathrm{N}$ supply by millet and spontaneous fallow vegetation, which certainly also mineralized more slowly, due to its higher $\mathrm{C} / \mathrm{N}$ ratio (Boer et al., 2008; Silva et al., 2009; Carvalho et al., 2011; Pacheco et al., 2013), as shown in Table 1.

The highest rice grain yield when $\mathrm{N}$ from urea was not applied or was only applied at sowing was obtained when legume cover crops were used, compared to millet or fallow (Table 2). The application of $\mathrm{N}$ at sowing + as topdressing provided similar grain yield regardless of the cover crop used. This shows that the application of $\mathrm{N}$ at sowing and of $60 \mathrm{~kg} \mathrm{ha}^{-1} \mathrm{~N}$ as topdressing was sufficient to supply the nutrient demand in the treatments using millet or fallow. However, the grain yield for these treatments was similar to those with legume cover crops and $\mathrm{N}$ application only at sowing. This result indicates that when these legume cover crop species are used after upland rice, $\mathrm{N}$ topdress application may be avoided, which is not the case for millet or fallow. This effect was also observed in other studies (Muraoka et al., 2002; Scivittaro et al., 2005). Gitti et al. (2012) found that when the previous legume crop affected rice yield, the largest yield was

Table 2. Rice (Oryza sativa) grain yield $\left(\mathrm{kg} \mathrm{ha}^{-1}\right)$ as affected by rates of $\mathrm{N}$ from urea and cover crop species, in the municipality of Selvíria, in the state of Mato Grosso do Sul, Brazil $^{(1)}$.

\begin{tabular}{|c|c|c|c|c|c|}
\hline $\begin{array}{l}\mathrm{N} \text { rate } \\
\left(\mathrm{kg} \mathrm{ha}^{-1}\right)\end{array}$ & $\begin{array}{c}\text { Sunn hemp } \\
\text { (Crotalaria } \\
\text { juncea) }\end{array}$ & $\begin{array}{c}\text { Pigeon pea } \\
(\text { Cajanus } \\
\text { cajan })\end{array}$ & $\begin{array}{c}\text { Velvet bean } \\
\text { (Mucuna } \\
\text { pruriens) }\end{array}$ & $\begin{array}{c}\text { Pearl millet } \\
\text { (Pennisetum } \\
\text { glaucum) }\end{array}$ & Fallow \\
\hline$\overline{0}$ & $4,303 \mathrm{Ab}$ & $4,517 \mathrm{Ab}$ & $4,688 \mathrm{Ab}$ & $3,086 \mathrm{Bc}$ & $2,950 \mathrm{Bc}$ \\
\hline 20 & $5,305 \mathrm{Aa}$ & $5,153 \mathrm{Aa}$ & $5,426 \mathrm{Aa}$ & $3,951 \mathrm{Bb}$ & $4,161 \mathrm{Bb}$ \\
\hline $20+60$ & 5,881Aa & $5,333 \mathrm{Aa}$ & $5,699 \mathrm{Aa}$ & $5,215 \mathrm{Aa}$ & $5,175 \mathrm{Aa}$ \\
\hline
\end{tabular}


obtained after growing pigeon pea and the lowest one after growing brachiaria (Brachiaria spp.) and millet. In addition, $107 \mathrm{~kg} \mathrm{ha}^{-1} \mathrm{~N}$ as urea provided the greatest productivity of rice, regardless of the previous winter cover crop.

The legume cover crops sunn hemp, pigeon pea, and green velvet bean provided similar rice grain yields, which are higher than those obtained with millet or on fallow soil (Table 2). The contribution of legume $\mathrm{N}$ to the grain yield of rice grown in sequence was, on average, equivalent to applying $60 \mathrm{~kg} \mathrm{ha}^{-1} \mathrm{~N}$ as urea, when compared to that of rice grown in fallow soil or in succession to millet. Estimates on the effect of sunn hemp and velvet bean on rice grain yield have been reported to be equivalent to fertilization with $40 \mathrm{~kg} \mathrm{ha}^{-1}$ $\mathrm{N}$ as urea (Muraoka et al., 2002).

Rice straw yields (shoot biomass without grain) were: $6.80,6.58,6.43,5.31$, and $5.04 \mathrm{Mg} \mathrm{ha}^{-1}$, respectively, for cultivation in succession to sunn hemp, pigeon pea, green velvet bean, pearl millet, and spontaneous vegetation (fallow in the off-season). In relation to applied $\mathrm{N}$ rates, the straw yields were: 5.71, 5.97, and $6.42 \mathrm{Mg} \mathrm{ha}^{-1}$, respectively, for $\mathrm{N}$ rates of 0,20 , and $80 \mathrm{~kg} \mathrm{ha}^{-1}$. Therefore, considering the average grain yield, which was $4,722 \mathrm{~kg} \mathrm{ha}^{-1}$ (Table 2), the grain/ straw ratio was 0.74 . These values are close to those obtained by Souza et al. (2010), who evaluated lime and nitrogen rates in soil with similar characteristics to that used in the present study, when assessing the same rice cultivar (IAC 202).

It was observed that cover crops and $\mathrm{N}$ rate affected $\mathrm{N}$ content, $\mathrm{N}$ accumulation, and use efficiency of $\mathrm{N}$ from urea by the rice crop (Table 3). Ndfcc in upland rice was highest when grown in succession to a legume cover crop. Rice crop grown in succession to sunn hemp removed the highest amount of $\mathrm{N}$ from the cover crop residues (Table 3 ), both in straw and in grain. This may be possibly due to the higher amount of $\mathrm{N}$ provided to the soil by this legume, i.e., $196.9 \mathrm{~kg} \mathrm{ha}^{-1}$ (Table 1). The rice crop $\mathrm{N}$ uptakes from pigeon pea and green velvet bean were superior to that from millet. Most of the $\mathrm{N}$ taken up by rice, as well as the $\mathrm{N}$ from cover crops, was allocated in the grain (60\%), suggesting it is the main sink for this nutrient.

The use of mineralized $\mathrm{N}$ from three legume cover crop species by the rice crop was similar (7.6\%), but higher than that for millet $(5.8 \%)$. In relation to $\mathrm{N}$ rates, the use of $\mathrm{N}$ from crop residues was similar when 20 or $80 \mathrm{~kg} \mathrm{ha}^{-1} \mathrm{~N}$ were applied, but greater than that of treatments without $\mathrm{N}$ application at sowing (Table 3).

The cover crop species, rate and time of $\mathrm{N}$ application (at sowing or as topdressing) affected the rice crop's $\mathrm{N}$ content, $\mathrm{N}$ accumulation, and use of $\mathrm{N}$ from urea (Table 4). The average $\mathrm{N}$ uptake from urea fertilizer by the rice crop was $34.7 \%$, of which $19.6 \%$ was by grains and $15.1 \%$ by straw (shoot except

Table 3. Nitrogen accumulation (straw and grain), percentage (Ndfcc), and quantity (QNdfcc) in rice plant derived from cover crops, and $\mathrm{N}$ use efficiency (NUE) as affected by $\mathrm{N}$ rates and cover crop species, in the municipality of Selvíria, in the state of Mato Grosso do Sul, Brazil ${ }^{(1)}$.

\begin{tabular}{|c|c|c|c|c|c|c|c|c|c|c|c|}
\hline \multirow[t]{3}{*}{ Cover crop } & \multicolumn{2}{|c|}{ Accumulated $\mathrm{N}$} & \multicolumn{2}{|c|}{${ }^{15} \mathrm{~N}$ enrichment } & \multicolumn{2}{|c|}{ Ndfcc } & \multicolumn{2}{|c|}{ QNdfcc } & \multicolumn{3}{|c|}{ NUE } \\
\hline & Straw & Grain & Straw & Grain & Straw & Grain & Straw & Grain & Straw & Grain & Total \\
\hline & \multicolumn{2}{|c|}{-----(kg ha $\left.{ }^{-1}\right)-----$} & \multicolumn{4}{|c|}{-1\% } & \multicolumn{2}{|c|}{------( $\left(\mathrm{kg} \mathrm{ha}^{-1}\right)-----$} & \multicolumn{3}{|c|}{ 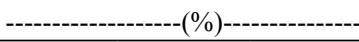 } \\
\hline $\begin{array}{l}\text { Sunn hemp } \\
\text { (Crotalaria juncea) }\end{array}$ & $43.6 b$ & $56.6 \mathrm{ab}$ & $0.556 \mathrm{a}$ & $0.590 \mathrm{a}$ & $13.7 \mathrm{a}$ & $16.1 \mathrm{a}$ & $6.0 \mathrm{a}$ & $8.9 \mathrm{a}$ & $3.04 \mathrm{a}$ & $4.54 \mathrm{a}$ & $7.68 \mathrm{a}$ \\
\hline $\begin{array}{l}\text { Pigeon pea } \\
\text { (Cajanus cajan) }\end{array}$ & $38.3 \mathrm{bc}$ & $57.1 \mathrm{ab}$ & $0.485 b$ & $0.491 b$ & $10.3 \mathrm{ab}$ & $10.8 b$ & $4.0 \mathrm{~b}$ & $6.2 b$ & $2.78 \mathrm{a}$ & $4.32 \mathrm{a}$ & $7.10 \mathrm{a}$ \\
\hline $\begin{array}{l}\text { Velvet bean } \\
\text { (Mucuna pruriens) }\end{array}$ & $43.8 \mathrm{a}$ & $60.0 \mathrm{a}$ & $0.512 \mathrm{ab}$ & $0.517 \mathrm{ab}$ & $8.4 \mathrm{bc}$ & $8.7 \mathrm{c}$ & $3.7 \mathrm{~b}$ & $5.1 \mathrm{c}$ & $3.35 \mathrm{a}$ & $4.69 \mathrm{a}$ & $8.04 \mathrm{a}$ \\
\hline $\begin{array}{l}\text { Pearl millet } \\
\text { (Pennisetum glaucum) }\end{array}$ & $34.0 \mathrm{c}$ & $46.7 b$ & $0.484 b$ & $0.493 b$ & $5.6 \mathrm{c}$ & $6.0 \mathrm{~d}$ & $2.0 \mathrm{c}$ & $2.9 \mathrm{~d}$ & $2.33 \mathrm{a}$ & $3.47 \mathrm{~b}$ & $5.80 \mathrm{~b}$ \\
\hline \multicolumn{12}{|l|}{$\mathrm{N}$ rate $\left(\mathrm{kg} \mathrm{ha}^{-1}\right)$} \\
\hline 0 & $33.3 \mathrm{c}$ & $42.9 \mathrm{c}$ & $0.516 \mathrm{a}$ & $0.540 \mathrm{a}$ & $9.4 \mathrm{a}$ & $10.9 \mathrm{a}$ & $3.3 \mathrm{a}$ & $4.8 b$ & $2.35 b$ & $3.45 \mathrm{~b}$ & $5.80 \mathrm{~b}$ \\
\hline 20 & $39.9 b$ & $54.8 \mathrm{~b}$ & $0.516 \mathrm{a}$ & $0.539 \mathrm{a}$ & $9.4 \mathrm{a}$ & $10.8 \mathrm{a}$ & $3.9 \mathrm{a}$ & $6.2 \mathrm{a}$ & $2.81 \mathrm{ab}$ & $4.39 \mathrm{a}$ & $7.20 \mathrm{a}$ \\
\hline 80 & $46.6 \mathrm{a}$ & $67.6 \mathrm{a}$ & $0.523 \mathrm{a}$ & $0.518 \mathrm{a}$ & $9.8 \mathrm{a}$ & $9.5 b$ & $4.5 \mathrm{a}$ & $6.4 \mathrm{a}$ & $3.46 \mathrm{a}$ & $4.93 a$ & $8.39 a$ \\
\hline Average & 39.9 & 55.1 & 0.518 & 0.532 & 9.5 & 10.4 & 3.9 & 5.8 & 2.88 & 4.25 & 7.13 \\
\hline $\mathrm{CV}(\%)$ & 8.0 & 12.3 & 14.0 & 9.8 & 24.5 & 9.2 & 25.6 & 9.8 & 25.0 & 11.1 & 12.9 \\
\hline
\end{tabular}

${ }^{(1)}$ Values followed by equal letters in the columns, for the same variable, do not differ by Tukey's test, at 5\% probability. 
grains). The efficiency of $\mathrm{N}$ fertilizers is commonly low, with a recovery estimated, on overall average, to be around $50 \%$ of the total applied N (Raun et al., 2002; Chien et al., 2009). In the present study, at the rate of $80 \mathrm{~kg} \mathrm{ha}^{-1} \mathrm{~N}$, the use efficiency of $\mathrm{N}$ from urea by upland rice was only $25.4 \%$ (Table 4 ).

Regardless of the species, rice crop grown in succession to the legume, especially pigeon pea, provided higher use of $\mathrm{N}$ from urea, when compared to millet or spontaneous vegetation (fallow during the offseason) (Table 4). This can be attributed to the fact that the legumes sunn hemp, green velvet bean, and pigeon pea had higher $\mathrm{N}$ concentration in dry matter and lower $\mathrm{C} / \mathrm{N}$ ratio than millet and spontaneous vegetation, with lower $\mathrm{N}$ immobilization by quimiorganotrophic microorganisms (Perin et al., 2004; Carvalho et al., 2011; Teodoro et al., 2011). Scivittaro et al. (2004) conducted an experiment to determine the temporal pattern of $\mathrm{N}$ release from velvet bean (Mucuna aterrima Merr.) and the dynamics of $\mathrm{N}$ in the cover crop in a soil-plant system, and found that the incorporation of cover crop promoted increased dry matter yield and $\mathrm{N}$ uptake by rice plants.

The application of $\mathrm{N}$ to rice at sowing caused lower $\mathrm{N}$ use by the crop for all treatments, when compared to $\mathrm{N}$ application at sowing and as topdressing (Table 4).
Total $\mathrm{N}$ application at sowing was as feasible as the fractionation of traditional $\mathrm{N}$ use at sowing and as topdressing. In a study carried by Arf et al. (2015), N application time did not affect grain yield of upland rice under no-tillage. However, Lopes et al. (2013) found that the application of $\mathrm{N}$ fertilizer fully at sowing was also as feasible as the fractionation of the traditional $\mathrm{N}$ use at sowing and as topdressing, for highland rice grown in the Cerrado.

Muraoka et al. (2002) showed that the cover crops velvet bean and sunn hemp provided higher fertilizer-N use efficiency, of $79 \%$, for upland rice crop under rainfed conditions. The authors reported that the cover crop effect is equivalent to the application of $40 \mathrm{~kg} \mathrm{ha}^{-1}$ mineral $\mathrm{N}$, and is, therefore, an alternative $\mathrm{N}$ supplement for this crop. The amount of $\mathrm{N}$ accumulated in SDM was 362 and $149 \mathrm{~kg} \mathrm{ha}^{-1} \mathrm{~N}$, respectively, for velvet bean and sunn hemp.

In most studies in which cover crops are combined with a mineral $\mathrm{N}$ source, there is a synergistic effect on the use of $\mathrm{N}$ from these sources, i.e., a priming effect (Muraoka et al., 2002; Scivittaro et al., 2005; Silva et al., 2006). This is because of the importance of cover crops incorporating to the soil other nutrients and organic compounds that favor the development of the root system and the biological activity that mediates

Table 4. Nitrogen accumulation (straw and grain), percentage (Ndff), and quantity (QNdff) in rice plant derived from fertilizer (urea), and $\mathrm{N}$ use efficiency (NUE) as affected by $\mathrm{N}$ rates and cover crop species, in the municipality of Selvíria, in the state of Mato Grosso do Sul, Brazil ${ }^{(1)}$.

\begin{tabular}{|c|c|c|c|c|c|c|c|c|c|c|c|}
\hline \multirow{3}{*}{ Cover crop } & \multicolumn{2}{|c|}{ Accumulated N } & \multicolumn{2}{|c|}{${ }^{15} \mathrm{~N}$ enrichment } & \multicolumn{2}{|c|}{ Ndff } & \multicolumn{2}{|c|}{ QNdff } & \multicolumn{3}{|c|}{ NUE } \\
\hline & Straw & Grain & Straw & Grain & Straw & Grain & Straw & Grain & Straw & Grain & Total \\
\hline & \multicolumn{2}{|c|}{-------(kg ha-1)------ } & ---------. & - & )------- & ---------- & \multicolumn{2}{|c|}{------(kg ha-1)------ } & ------------ & $-(\%)-$ & ---- \\
\hline $\begin{array}{l}\text { Sunn hemp } \\
\text { (Crotalaria juncea) }\end{array}$ & $0.599 \mathrm{~b}$ & $0.689 \mathrm{a}$ & $59.5 \mathrm{a}$ & $67.8 \mathrm{ab}$ & $9.3 b$ & $12.9 \mathrm{a}$ & $5.3 \mathrm{a}$ & $8.7 \mathrm{a}$ & $13.23 \mathrm{ab}$ & $20.92 a$ & $34.15 b$ \\
\hline $\begin{array}{l}\text { Pigeon pea } \\
\text { (Cajanus cajan) }\end{array}$ & $0.681 \mathrm{ab}$ & $0.751 \mathrm{a}$ & $45.6 \mathrm{ab}$ & $59.0 \mathrm{abc}$ & 12.6ab & $15.4 \mathrm{a}$ & $5.7 \mathrm{a}$ & $9.0 \mathrm{a}$ & $22.69 \mathrm{a}$ & $20.19 a$ & $42.88 \mathrm{a}$ \\
\hline $\begin{array}{l}\text { Velvet bean } \\
\text { (Mucuna pruriens) }\end{array}$ & $0.679 \mathrm{ab}$ & $0.684 \mathrm{a}$ & $52.3 \mathrm{ab}$ & $69.0 \mathrm{a}$ & $12.5 \mathrm{ab}$ & $12.7 \mathrm{a}$ & $6.3 \mathrm{a}$ & $8.4 \mathrm{a}$ & $15.94 \mathrm{ab}$ & $21.05 \mathrm{a}$ & $36.99 b$ \\
\hline $\begin{array}{l}\text { Pearl millet } \\
\text { (Pennisetum glaucum) }\end{array}$ & $0.746 a b$ & $0.756 a$ & $38.1 \mathrm{bc}$ & $55.6 \mathrm{bc}$ & $15.2 \mathrm{ab}$ & $15.6 \mathrm{a}$ & $5.0 \mathrm{a}$ & $8.3 \mathrm{a}$ & $11.43 b$ & $17.56 \mathrm{a}$ & $28.98 \mathrm{c}$ \\
\hline Fallow & $0.801 \mathrm{a}$ & $0.799 a$ & $30.4 \mathrm{c}$ & $51.9 \mathrm{c}$ & $17.4 \mathrm{a}$ & $17.3 \mathrm{a}$ & $5.0 \mathrm{a}$ & $8.9 \mathrm{a}$ & $12.32 \mathrm{ab}$ & $18.06 \mathrm{a}$ & $30.39 \mathrm{c}$ \\
\hline \multicolumn{12}{|l|}{$\mathrm{N}$ rate $\left(\mathrm{kg} \mathrm{ha}^{-1}\right)$} \\
\hline $20^{(2)}$ & $0.596 \mathrm{~b}$ & $0.514 b$ & $44.0 \mathrm{a}$ & $51.7 \mathrm{c}$ & $9.2 b$ & $5.9 \mathrm{~b}$ & $3.9 \mathrm{~b}$ & $3.0 \mathrm{~b}$ & $19.59 \mathrm{ab}$ & $14.87 \mathrm{~b}$ & $34.46 \mathrm{ab}$ \\
\hline $20^{(2)}+60$ & $0.579 \mathrm{~b}$ & $0.539 b$ & $50.2 \mathrm{a}$ & $70.1 \mathrm{a}$ & $8.5 b$ & $6.9 \mathrm{~b}$ & $4.2 \mathrm{~b}$ & $4.8 \mathrm{~b}$ & $20.91 \mathrm{a}$ & $23.87 \mathrm{a}$ & $44.78 \mathrm{a}$ \\
\hline $20+60^{(2)}$ & $0.816 \mathrm{a}$ & $0.946 \mathrm{a}$ & $41.4 \mathrm{a}$ & $62.5 \mathrm{ab}$ & $18.0 \mathrm{a}$ & $23.2 \mathrm{a}$ & $6.7 \mathrm{a}$ & $13.8 \mathrm{a}$ & $11.10 \mathrm{bc}$ & $22.94 \mathrm{ab}$ & $34.04 \mathrm{ab}$ \\
\hline $80^{(2)}$ & $0.811 \mathrm{a}$ & $0.944 \mathrm{a}$ & $45.1 \mathrm{a}$ & $58.4 \mathrm{bc}$ & $17.8 \mathrm{a}$ & $23.1 \mathrm{a}$ & 7.1a & $13.2 \mathrm{a}$ & $8.89 \mathrm{c}$ & $16.54 b$ & $25.43 b$ \\
\hline Average & 0.701 & 0.736 & 45.18 & 60.7 & 13.4 & 14.8 & 5.5 & 8.7 & 15.10 & 19.60 & 34.70 \\
\hline $\mathrm{CV}(\%)$ & 16.0 & 18.2 & 14.6 & 13.6 & 16.2 & 17.8 & 16.2 & 19.8 & 19.6 & 13.5 & 14.7 \\
\hline
\end{tabular}

${ }^{(1)}$ Values followed by equal letters in the columns, for the same variable, do not differ by Tukey's test, at $5 \%$ probability. ${ }^{(2)}$ Labeled with ${ }^{15} \mathrm{~N}$. 
the mineralization process of organic materials. Other benefits are also observed in the physical environment, such as moisture, temperature and aeration, and in mycorrhizae, reflecting a greater capacity to absorb water and nutrients.

Regardless of the plant species used as a cover crop for $\mathrm{N}$ supply, the soil was the major source of $\mathrm{N}$ for rice, providing more than two-thirds of the $\mathrm{N}$ taken up by the crop (Figure 1). Scivittaro et al. (2004) also detected that the soil was the main source of $\mathrm{N}$ for corn (Zea mays L.). However, most of the $\mathrm{N}$ from fertilizer and, mainly, from cover crops was not used immediately by the rice crop after application (Tables 3 and 4, and Figure 1).

It is important to note that both the use of $\mathrm{N}$ from cover crops and urea in the present study are underestimated, since there was no accumulation of $\mathrm{N}$ in the rice root system nor in the root system of the cover crops, as reported by Silva et al. (2008) and Contreras Espinal (2016).

$\mathrm{Li}$ et al. (2015) verified that the application of $\mathrm{N}$ fertilizer in combination with green manure enhanced wheat (Triticum aestivum L.) yield and fertilizer-N

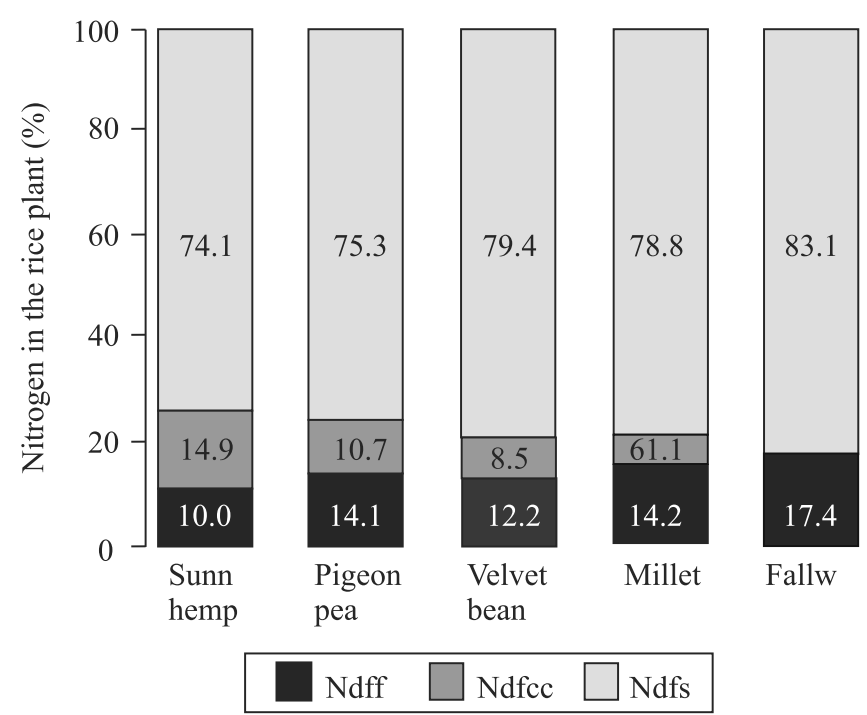

Figure 1. Relative contribution of the evaluated $\mathrm{N}$ sources, at a rate of $80 \mathrm{~kg} \mathrm{ha}^{-1} \mathrm{~N}$ : urea (Ndff), cover crops (Ndfcc), and soil (Ndfs), for $\mathrm{N}$ accumulated in shoots (grain + straw), as affected by $\mathrm{N}$ rates and cover crop species, in the municipality of Selvíria, in the state of Mato Grosso do Sul, Brazil. The species studied were: rice (Oryza sativa), sunn hemp (Crotalaria juncea), pigeon pea (Cajanus cajan), velvet bean (Mucuna pruriens), and millet (Pennisetum glaucum). use efficiency. Furthermore, Zhu et al. (2014) found that Chinese milk vetch (Astragalus sinicus L.) was an efficient $\mathrm{N}$ source, alternative to chemical fertilizer, in the intensive double-rice cropping systems, i.e., two rice crops per year, adopted in China. As also observed in a pot experiment (Contreras Espinal et al., 2016), the results of the present study showed that there is an opportunity to both reduce mineral $\mathrm{N}$-fertilizer inputs and increase the yield of upland rice and other crops in dryland grown in succession to a legume cover crop, under no-tillage, which are important considerations in the Brazilian context, in which resources are limited and there is a need to improve the crop's productivity and environmental sustainability.

\section{Conclusions}

1. The use of legume cover crops compared to fallow and split application of $\mathrm{N}$ improves $\mathrm{N}$ content, $\mathrm{N}$ accumulation, and fertilizer- $\mathrm{N}$ use efficiency by upland rice (Orzya sativa).

2. The inclusion of legume cover crops in a cropping system results in greater upland rice grain yield and use efficiency of $\mathrm{N}$ from fertilizer, when compared to pearl millet (Pennisetum glaucum) or spontaneous vegetation (fallow in off-season).

3 . The use of legume cover crops in no-tillage has the potential to supply $\mathrm{N}$ for upland rice equivalent to applying $60 \mathrm{~kg} \mathrm{ha}^{-1} \mathrm{~N}$ as urea.

4. The urea-N use efficiency by upland rice ranges from 25 to $45 \%$, depending on $\mathrm{N}$ rate and application time, whereas the $\mathrm{N}$ use efficiency by cover crops ranges from 5.8 to $8 \%$.

5 . The previously grown legume cover crop is an important source of $\mathrm{N}$ to upland rice, improves fertilizer-N use efficiency, and, therefore, has the potential to reduce the crop's $\mathrm{N}$ requirements.

\section{Acknowledgements}

To Fundação de Amparo à Pesquisa do Estado de São Paulo (Fapesp, Process No. 2008/54502-9), for the research scholarship granted to the first author and for financial support; to International Atomic Energy Agency (IAEA, Project No. RLA 5052), for financial support; and to Conselho Nacional de Desenvolvimento Científico e Tecnológico (CNPq), for the research fellowship to the other authors. 


\section{References}

ALVARES, C.A.; STAPE, J.L.; SENTELHAS, P.C.; GONÇALVES, J.L. de M.; SPAROVEK, G. Köppen's climate classification map for Brazil. Meteorologische Zeitschrift, v.22, p.711-728, 2013. DOI: 10.1127/0941-2948/2013/0507.

ARF, O.; RODRIGUES, R.A.F.; NASCENTE, A.S.; LACERDA, M.C. Adubação antecipada de nitrogênio na cultura do arroz de terras altas sob plantio direto. Revista de Ciências Agrárias, v.58, p.6-13, 2015. DOI: 10.4322/rca.1625.

ASAGI, N.; UENO, H. Nitrogen dynamics in paddy soil applied with various ${ }^{15} \mathrm{~N}$-labelled green manures. Plant and Soil, v.322, p.251-262, 2009. DOI: 10.1007/s11104-009-9913-4.

BARRIE, A.; PROSSER, S.J. Automated analysis of light-element stable isotopes by isotope ratio mass spectrometry. In: BOUTTON, T.W.; YAMASAKI, S. (Ed.). Mass spectrometry of soils. New York: Marcel Dekker, 1996. p.1-46.

BOER, C.A.; ASSIS, R.L. de; SILVA, G.P.; BRAZ, A.J.B.P.; BARROSO, A.L. de L.; CARGNELUTTI FILHO, A.; PIRES, F.R. Biomassa, decomposição e cobertura do solo ocasionada por resíduos culturais de três espécies vegetais na região Centro-Oeste do Brasil. Revista Brasileira de Ciência do Solo, v.32, p.843-851, 2008. DOI: 10.1590/S0100-06832008000200038.

BORDIN, L.; FARINELLI, R.; PENARIOL, F.G.; FORNASIERI FILHO, D. Sucessão de cultivo de feijão-arroz com doses de adubação nitrogenada após adubação verde, em semeadura direta. Bragantia, v.62, p.417-428, 2003. DOI: 10.1590/ S0006-87052003000300008.

CARVALHO, A.M. de; SOUZA, L.L.P. de; GUIMARÃES JÚNIOR, R.; ALVES, P.C.A.C.; VIVALDI, L.J. Cover plants with potential use for crop-livestock integrated systems in the Cerrado region. Pesquisa Agropecuária Brasileira, v.46, p.1200-1205, 2011. DOI: 10.1590/S0100-204X2011001000012.

CAZETTA, D.A.; ARF, O.; BUZETTI, S.; SÀ, M.E. de; RODRIGUES, R.A.F. Desempenho do arroz de terras altas com a aplicação de doses de nitrogênio e em sucessão às culturas de cobertura do solo em sistema de plantio direto. Bragantia, v.67, p.471-479, 2008. DOI: 10.1590/S0006-87052008000200023.

CHERR, C.M.; SCHOLBERG, J.M.S.; MCSORLEY, R. Green manure approaches to crop production: a synthesis. Agronomy Journal, v.98, p.302-319, 2006. DOI: 10.2134/agronj2005.0035.

CHIEN, S.H.; PROCHNOW, L.I.; CANTARELLA, H. Recent developments of fertilizer production and use to improve nutrient efficiency and minimize environmental impacts. Advances in Agronomy, v.102, p.267-322, 2009. DOI: 10.1016/ S0065-2113(09)01008-6.

CONTRERAS ESPINAL, F.S.; SILVA, E.C. da; MURAOKA, T.; FRANZINI, V.I.; TRIVELIN, P.C.O.; TEIXEIRA, M.T.; SAKADEVAN, K. Utilization of nitrogen $\left({ }^{15} \mathrm{~N}\right)$ from urea and green manures by rice as affected by nitrogen fertilizer rate. African Journal of Agricultural Research, v.11, p.1171-1180, 2016. DOI: 10.5897/AJAR2015.10684.

FAGERIA, N.K.; BALIGAR, V.C.; BAILEY, B.A. Role of cover crops in improving soil and row crop productivity.
Communications in Soil Science and Plant Analysis, v.36, p.2733-2757, 2005. DOI: 10.1080/00103620500303939.

FAGERIA, N.K.; BALIGAR, V.C.; LI, Y.C. The role of nutrient efficient plants in improving crop yields in the Twenty First Century. Journal of Plant Nutrition, v.31, p.1121-1157, 2008. DOI: $10.1080 / 01904160802116068$.

FAGERIA, N.K.; MORAIS, O.P. de; SANTOS, A.B. dos. Nitrogen use efficiency in upland rice genotypes. Journal of Plant Nutrition, v.33, p.1696-1711, 2010. DOI: 10.1080/01904167.2010.496892.

FAGERIA, N.K.; MOREIRA, A.; COELHO, A.M. Yield and yield components of upland rice as influenced by nitrogen sources. Journal of Plant Nutrition, v.34, p.361-370, 2011. DOI: 10.1080/01904167.2011.536878.

GITTI, D. de C.; ARF, O.; PORTUGAL, J.R.; CORSINI, D.C.D.C.; RODRIGUES, R.A.F.; KANEKO, F.H. Coberturas vegetais, doses de nitrogênio e inoculação de sementes com Azospirillum brasilense em arroz de terras altas no sistema plantio direto. Bragantia, v.71, p.509-517, 2012. DOI: 10.1590/S0006-87052013005000002.

HOLZSCHUH, M.J.; BOHNEN, H.; ANGHINONI, I.; MEURER, E.J.; CARMONA, F. de C.; COSTA, S.E.V.G. de A. Resposta do arroz irrigado ao suprimento de amônio e nitrato. Revista Brasileira de Ciência do Solo, v.33, p.1323-1331, 2009. DOI: 10.1590/S0100-06832009000500025.

INTERNATIONAL ATOMIC ENERGY AGENCY. Use of isotope and radiation methods in soil and water management and crop nutrition. Vienna: IAEA, 2001. 247p. (Training course series, 14).

LI, F.C.; WANG, Z.H.; DAI, J.; LI, Q.; WANG, X.; XUE, C.; LIU, H.; HE, G. Fate of nitrogen from green manure, straw, and fertilizer applied to wheat under different summer fallow management strategies in dryland. Biology and Fertility of Soils, v.51, p.769-780, 2015. DOI: 10.1007/S00374-015-1023-2.

LOPES, R.A.; BUZETTI, S.; TEIXEIRA FILHO, M.C.M.; BENETT, C.G.S.; ARF, M.V. Doses, fontes e épocas de aplicação de nitrogênio em arroz de terras altas cultivado em sistema de semeadura direta. Revista Caatinga, v.26, p.79-87, 2013.

MORO, E.; CRUSCIOL, C.A.C.; CANTARELLA, H.; NASCENTE, A.S. Upland rice under no-tillage preceded by crops for soil cover and nitrogen fertilization. Revista Brasileira de Ciência do Solo, v.37, p.1669-1677, 2013. DOI: 10.1590/ S0100-06832013000600023.

MURAOKA, T.; AMBROSANO, E.J.; ZAPATA, F.; BORTOLETTO, N.; MARTINS, A.L.M.; TRIVELIN, P.C.O.; BOARETTO, A.E.; SCIVITTARO, W.B. Eficiencia de abonos verdes (crotalaria y mucuna) y urea, aplicados solos o juntamente, como fuentes de $\mathrm{N}$ para el cultivo de arroz. Terra, v.20, p.17-23, 2002.

NASCENTE, A.S.; CRUSCIOL, C.A.C.; COBUCCI, T. The no-tillage system and cover crops - alternatives to increase upland rice yields. European Journal of Agronomy, v.45, p.124-131, 2013a. DOI: 10.1016/j.eja.2012.09.004.

NASCENTE, A.S.; CRUSCIOL, C.A.C.; COBUCCI, T.; VELINI, E.D. Cover crop termination timing on rice crop production in a no-till system. Crop Science, v.53, p.2659-2669, 2013b. DOI: 10.2135/cropsci2013.01.0047. 
NELSON, D.W.; SOMMERS, L.E. Total carbon, organic carbon, and organic matter. In: PAGE, A.L.; MILLER, R.H.; KEENEY, D.R. (Ed.). Methods of soil analysis: chemical and microbiological properties. $2^{\text {nd }}$ ed. Madison: American Society of Agronomy: Soil Science Society of America, 1982. Part 2, p.539-579. (Agronomy series, 9).

PACHECO, L.P.; BARBOSA, J.M.; LEANDRO, W.M.; MACHADO, P.L.O. de A.; ASSIS, R.L. de; MADARI, B.E.; PETTER, F.A. Ciclagem de nutrientes por plantas de cobertura e produtividade de soja e arroz em plantio direto. Pesquisa Agropecuária Brasileira, v.48, p.1228-1236, 2013. DOI: 10.1590/ S0100-204X2013000900006.

PERIN, A.; SANTOS, R.H.S.; URQUIAGA, S.; GUERRA, J.G.M.; CECON, P.R. Produção de fitomassa, acúmulo de nutrientes e fixação biológica de nitrogênio por adubos verdes em cultivo isolado e consorciado. Pesquisa Agropecuária Brasileira, v.39, p.35-40, 2004. DOI: 10.1590/S0100-204X2004000100005.

RAIJ, B. van; ANDRADE, J.C. de; CANTARELLA, H.; QUAGGiO, J.A (Ed.). Análise química para avaliação da fertilidade de solos tropicais. Campinas: IAC, 2001. 285p.

RAUN, W.R.; SOLIE, J.B.; JOHNSON, G.V.; STONE, M.L.; MULLEN, R.W.; FREEMAN, K.W.; THOMASON, W.E.; LUKINA, E.V. Improving nitrogen use efficiency in cereal grain production with optical sensing and variable rate application. Agronomy Journal, v.94, p.815-820, 2002. DOI: 10.2134/ agronj2002.8150.

SANTOS, A.B. dos; RABELO, R.R. (Ed.). Informações técnicas para a cultura do arroz irrigado no Estado do Tocantins. Santo Antônio de Goiás: Embrapa Arroz e Feijão, 2008. 136p. (Embrapa Arroz e Feijão. Documentos, 218).

SANTOS, H.G. dos; JACOMINE, P.K.T.; ANJOS, L.H.C. dos; OLIVEIRA, V.A. de; LUMBRERAS, J.F.; COELHO, M.R.; ALMEIDA, J.A. de; CUNHA, T.J.F.; OLIVEIRA, J.B. de. Sistema brasileiro de classificação de solos. 3.ed. rev. e ampl. Brasília: Embrapa, 2013. 353p.

SCIVITTARO, W.B.; MURAOKA, T.; BOARETTO, A.E.; TRIVELIN, P.C.O. Fate of nitrogen $\left({ }^{15} \mathrm{~N}\right)$ from velvet bean in the soil-plant system. Scientia Agricola, v.61, p.210-215, 2004. DOI: 10.1590/S0103-90162004000200014.

SCIVITTARO, W.B.; SILVA, C.A.S. da; REIS, J.C.L.; MURAOKA, T.; TRIVELIN, P.C.O. Potencial de fornecimento de nitrogênio $\left({ }^{15} \mathrm{~N}\right)$ de adubos verdes para o arroz irrigado. Pelotas: Embrapa Clima Temperado, 2005. 22p. (Embrapa Clima Temperado. Boletim de Pesquisa e Desenvolvimento, 21).

SCIVITTARO, W.B.; SILVA, C.A.S. da; REIS, J.C.L. Racionalização da aplicação de fertilizante nitrogenado na produção de arroz irrigado. Pelotas: Embrapa Clima
Temperado, 2008. 6p. (Embrapa Clima Temperado. Comunicado técnico, 200).

SILVA, E.C. da; MURAOKA, T.; ALVAREZ VILLANUEVA, F.C.; CONTRERAS ESPINAL, F.S. Aproveitamento de nitrogênio pelo milho, em razão da adubação verde, nitrogenada e fosfatada. Pesquisa Agropecuária Brasileira, v.44, p.118-127, 2009. DOI: 10.1590/S0100-204X2009000200002.

SILVA, E.C. da; MURAOKA, T.; BUZETTI, S.; CONTRERAS ESPINAL, F.S.; TRIVELIN, P.C.O. Utilização do nitrogênio da palha de milho e de adubos verdes pela cultura do milho. Revista Brasileira de Ciência do Solo, v.32, p.2853-2861, 2008. DOI: 10.1590/S0100-06832008000700032.

SILVA, E.C. da; MURAOKA, T.; BUZETTI, S.; VELOSO, M.E. da C.; TRIVELIN, P.C.O. Aproveitamento do nitrogênio $\left({ }^{15} \mathrm{~N}\right)$ da crotalária e do milheto pelo milho sob plantio direto em Latossolo Vermelho de Cerrado. Ciência Rural, v.36, p.739-746, 2006. DOI: 10.1590/S0103-84782006000300004.

SOUZA, L.C.D. de; SÁ, M.E.; MARTINS, H.S.D.; ABRANTES, F.L.; SILVA, M.P. da; ARRUDA, N. Produtividade e qualidade de sementes de arroz em resposta a doses de calcário e nitrogênio. Revista Trópica: Ciências Agrárias e Biológicas, v.4, p.27-35, 2010.

TEIXEIRA, C.M.; CARVALHO, G.J. de; ANDRADE, M.J.B. de; SILVA, C.A.; PEREIRA, J.M. Decomposição e liberação de nutrientes das palhadas de milheto e milheto + crotalária no plantio direto do feijoeiro. Acta Scientiarum. Agronomy, v.31, p.647-653, 2009. DOI: 10.4025/actasciagron.v31i4.1356.

TEJADA, M.; GONZALEZ, J.L.; GARCÍA-MARTÍNEZ, A.M.; PARRADO, J. Application of a green manure and green manure composted with beet vinasse on soil restoration: effects on soil properties. Bioresource Technology, v.99, p.4949-4957, 2008. DOI: 10.1016/j.biortech.2007.09.026.

TEODORO, R.B.; OLIVEIRA, F.L. de; SILVA, D.M.N. da; FÁVERO, C.; QUARESMA, M.A.L. Aspectos agronômicos de leguminosas para adubação verde no Cerrado do Alto Vale do Jequitinhonha. Revista Brasileira de Ciência do Solo, v.35, p.635-643, 2011. DOI: 10.1590/S0100-06832011000200032.

TORRES, J.L.R.; PEREIRA, M.G.; FABIAN, A.J. Produção de fitomassa por plantas de cobertura e mineralização de seus resíduos em plantio direto. Pesquisa Agropecuária Brasileira, v.43, p.421-428, 2008. DOI: 10.1590/S0100-204X2008000300018.

UNITED STATES DEPARTMENT OF AGRICULTURE. Keys to soil taxonomy. $11^{\text {th }}$ ed. Washington: USDA, NRCS, 2010. 338p.

ZHU, B.; YI, L.; HU, Y.; ZENG, Z.; LIN, C.; TANG, H.; YANG, G.; $\mathrm{XIAO}, \mathrm{X}$. Nitrogen release from incorporated ${ }^{15} \mathrm{~N}$-labelled Chinese milk vetch (Astragalus sinicus L.) residue and its dynamics in a double rice cropping system. Plant and Soil, v.374, p.331-344, 2014. DOI: $10.1007 / \mathrm{s} 11104-013-1808-8$. 